\title{
Case Studies of University Funds Source Structure Impact on University Rankings in U.S.
}

\author{
Shujuan Zhang \\ Education College in Capital Normal University \\ Education College, CNU \\ Beijing, China \\ nmgzsj.love@163.com
}

\author{
Ling $\mathrm{Xu} *$ \\ Education College in Capital Normal University \\ Education College, CNU \\ Beijing, China \\ cnuxuling555@163.com
}

\begin{abstract}
This article, by adopting two indicators based on evaluation index system named U.S. News And World Report in the "financial position" and "the proportion of alumni donations" and selecting two universities empirical study, finds that there is a linear correlation between U.S. total funds amount for university funds and university rankings; the difference of the university funds source structure has led to the different university rankings.
\end{abstract}

Keywords-funds source structure; U.S. university rankings; university rankings index system

\section{PUTTING FORWARD THE INTERRELATED PROBLEMS}

The United States has the most advanced system of higher education in the world. And how does it work? Funds is one of the important factors which is affecting the normal operation of each university. According to the nature of the university, American universities can be divided into public universities and private universities. Whatever, its funds source structure consists of financial allocation by the government and non-government fiscal expenditure composition, and the main difference is the proportion of funds allocated. However, since 2008 in U.S., the financial crisis, a large number of enterprises and banks failed, seriously affected the government taxes as the main source of fiscal revenue and the private financing to donate as the main source of non-fiscal revenues, which affected the use of funds for universities. This paper mainly studied the decades before and after the financial crisis, the change of the U.S. university funds source structure impacts on university rankings, and the study is aim to design for the modern university management and future development of reference.

\section{OVERVIEW OF THE UNIVERSITY RANKINGS INDEX SYSTEM}

American University rankings is based on professional assessment indicators, which contains teachers colleges and universities, situation of students, funds and other aspects of the comprehensive assessment index system, issued by the agency's assessment. Different indicators system, the influence of university rankings is different. There are different forms and different nature of the professional rating agencies in U.S., and each has its own evaluation criteria and evaluation system.

Carnegie Classification of Institutions of Higher Education in the 1970 s by the Clark Kerr under the leadership of the Carnegie Commission on Higher Education
Development, was originally developed as a research tool, used at the foundation's report for the first time in 1971, and officially announced in 19731. After several amendments, formed a tight classification system of higher education, and finally in 2005 launched the latest version of the multi-dimensional classification. As the basic standards of higher education, Carnegie Classification of Institutions of Higher Education impacts on constituting of assessment index system of higher education, such as the U.S. News and World Report. University presidents are often concerned about the results of the Carnegie classification, used to assess and identify with their school's academic position, to study and compare the differences among other competitors2.Highlighted below US News and World Report.

\section{A. U.S. News and World Report}

The credibility of American news media has always been favored by the public. Its periodic release of "university ranking" is an effective channel for the public to spread university information. In 1983, US News and World Report(US.NWP) first introduced biennial ranking American undergraduate education institutions. Since 1987, it extended to postgraduate education evaluation and changed once a year. According to Carnegie Classification of Institutions of Higher Education, U.S.NWP described the nature of 1323 universities from two dimensions "National institutions and local institutions", and finally, formed Evaluation Index System(Table 1).The agency for university rankings index system established by index weights were academic reputation (25\%), student retention rates $(20 \%-25 \%)$, teacher status $(20 \%)$, students choose $(15 \%)$, financial situation $(10 \%)$, value added $(5 \%)$ and alumni giving rate $(5 \%)$. In the second indicators of each first indicator have a detailed explanation. Among them, the "financial condition" and "the proportion of alumni donations", respectively, is in an index accounted for $10 \%$ and $5 \%$. Visibly, the importance of funding for university rankings is obvious.

Well, what is about $15 \%$ of the funding source constitute of? We need to further study the structure of the university funding source. This article will be based on the U.S.NWP released the latest university evaluation system, and use "the evaluation of the financial position" and "alumni donations proportion" of the four-year national universities to evaluate the structure of funds source impacting on the university rankings. The specific research hypothesises are, first, the 
amount of total investment in university funding for university rankings is influential, the more input, the more front rank; second, university funds source structure is influential on university rankings, and finding the extent of the impacting is obtained.

\begin{tabular}{|c|c|c|}
\hline TABLE 1 & EVALUA & ON $\quad$ INDEX SYSTEM $^{3}$ \\
\hline $\begin{array}{l}\text { first grade } \\
\text { indexes }\end{array}$ & weight & Second grade indexes \\
\hline $\begin{array}{l}\text { Academic } \\
\text { reputation }\end{array}$ & $25 \%$ & $\begin{array}{l}\text { Only first indexes.( } 4 \text { Point } \\
\text { system) calculate the average } \\
\text { score by headmaster, } \\
\text { department officials, and } \\
\text { admissions officials of the } \\
\text { similar universities. }\end{array}$ \\
\hline $\begin{array}{l}\text { Situation of } \\
\text { students }\end{array}$ & $15 \%$ & $\begin{array}{l}\text { marks(40\%),class-ranking(35 } \\
\%) \text { in high } \begin{array}{r}\text { school, } \\
\text { acceptance }\end{array} \\
\text { results }(10 \%)\end{array}$ \\
\hline $\begin{array}{l}\text { The situation } \\
\text { of teachers }\end{array}$ & $20 \%$ & $\begin{array}{l}\text { class-size }(40 \%) \text {,teacher-salar } \\
\mathrm{y}(35 \%) \text {,teaching } \\
\text { degree }(15 \%) \text {, the } \\
\text { student-teacher ratio }(5 \%) \text {, the } \\
\text { proportion of full-time } \\
\text { faculty }(5 \%)\end{array}$ \\
\hline $\begin{array}{l}\text { Financial } \\
\text { position }\end{array}$ & $10 \%$ & $\begin{array}{l}\text { educational } \\
\text { expenses }(80 \%), \text { other } \\
\text { expenses }(20 \%)\end{array}$ \\
\hline $\begin{array}{l}\text { Student } \\
\text { retention }\end{array}$ & $\begin{array}{c}20 \% / 25 \\
\%\end{array}$ & $\begin{array}{lr}\text { regional universities }(25 \%), \\
\text { national universities }(20 \%), \\
\text { graduates } \quad \text { ratio }(80 \%), \\
\text { freshman retention rate }(20 \%)\end{array}$ \\
\hline added value & $5 \%$ & $\begin{array}{l}\text { The only used for national } \\
\text { universities and national } \\
\text { ARTS. }\end{array}$ \\
\hline $\begin{array}{l}\text { The } \\
\text { proportion of } \\
\text { alumni } \\
\text { donations }\end{array}$ & $5 \%$ & $\begin{array}{l}\text { The only set an indicator of } \\
\text { satisfaction with graduates of } \\
\text { his alma mater. }\end{array}$ \\
\hline
\end{tabular}

\section{CASE STUDY}

\section{A. University rankings}

With narrowed scope of research objectives, and the American University Rankings by U.S.NWP as basis, this study choose the financial crisis in 2008 as the reference period, and top 50 Research Universities in U.S., and choose one public university and one private university in them. After screening, we find, University of Wisconsin-Madison (UWM) and University of Southern California's(USC) place fluctuations significantly in the past 10 years. The rankings of UWM are $38,31,34,34,34,38,35,39,45,45$ (2003-2012), USC are 43, 31, 30, 30, 27, 27, 27, 26, 23, 23(2003-2012).4 It shows that, the rankings of University of Wisconsin-Madison is unstable in the past 10 years, especially, after the financial crisis in 2008; the rankings of University of Southern California is rising. Therefore, the two universities were selected as research subjects for a typical case comparison, to demonstrate 10 years(2002-2011) of changes in the funds source structure.

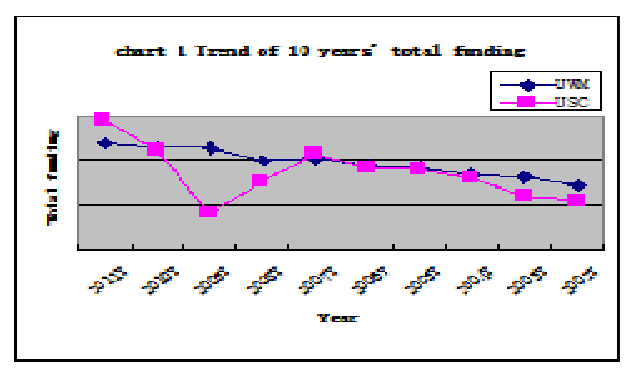

FIGURE I. TREND OF 10 YEARS' TOTAL FINDINGS

\section{B. Relation between total investment and university rankings}

Chart 1 shows that, the total investment of UWM is rising from 2002 to 2011; except 2009, the total investment of USC is also rising steadily in a little step. Except 2007 and 2011, the total investment of UWM is higher than USC, but the place is lower than USC. In addition, the total investment of USC is lower than UWM, but the place is steady. In short, the two universities are inverse ratio between total investment and rankings (chart 1).Therefore, the university's total investment is not absolutely impacting on the university rankings, but perhaps, it is one of the factors, so the first hypothesis is not right.

\section{Relation between funds resource structure and university rankings}

From the university funds resource structure, university funds consists of government and non-government fiscal expenditure. Government fiscal expenditure contains government appropriations (1) and government grants and contracts (2); non-government fiscal expenditure contains tuition and fees (3), private gifts, grants, contracts (4), investment income (5) and other core revenues (6). 


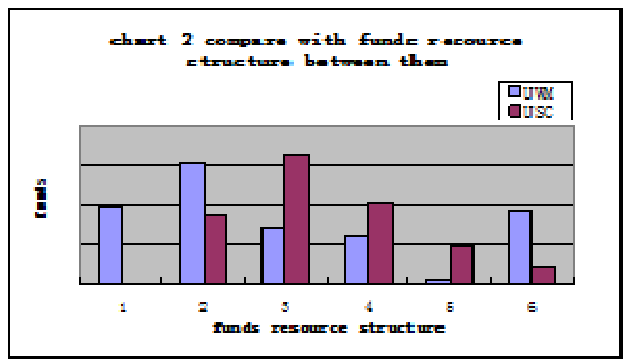

FIGURE II. COMPARE WITH FUNDS RESOURCE STRUCTURE BETWEEN THEM

In public universities, government fiscal expenditure is primary and in private universities, non-government fiscal expenditure is primary, such as private gifts, grants, contracts (chart 2). Funds of UWM is 52\% of total government financial expenditure $(\$ 10,031,764,742)$, where government appropriations(20\%), and government grants and contracts (32\%), non-governmental financial expenditure accounts for $48 \%$ of total, and the ratio is $1: 1$; funds of USC is $21 \%$ of total government financial expenditure $(\$ 3,527,602,000)$, and non-governmental financial expenditure accounts for $79 \%$ of total, and the ratio is $2: 8$. Therefore, compare with private universities, the government financial of the public universities supports for the larger universities, mainly in government appropriations(1) and government grants and contracts(2) mainly in two forms; private sources of funding mainly non-financial funds in tuition and fees(3), private donations and contracts(4). Then, what is the relationship between sources of funding structures and university rankings?

1) The correlation analysis between university funds source structure and university rankings

Table 2 shows that, UWM ranks with government appropriations (1), private donations and contracts (4) between the correlation coefficients are 0.749 and 0.758 . Level significantly below 0.05 , between them there exists positive correlation. Rankings and government grants and contracts (2), tuition and fees (3), investment income (5), and others (6) are no significant correlation between them. Therefore, UWM puts invest more government appropriations (1) and private donations and contracts(4), the more its better ranking it gets.

Table 2 also shows that, USC ranks with tuition and fees (3), private donations and contracts(4), other core revenues (6) between the correlation coefficients are $-0.987,-0.928$, and -0.852 . Level significantly below 0.05 , there exists between them highly negative correlation. Rankings and government grants and contracts (2), investment income (5) are no significant correlation between them. That is to say, USC's tuition and fees are charged by the more private donations and contracts as well as other sources of funding, the more its more high rankings. It should be noted that, due to USC is a private university, government grants and contracts have been not carried out, therefore, the Government allocated funding is not shown.
TABLE 2 CORRELATION ANALYSIS

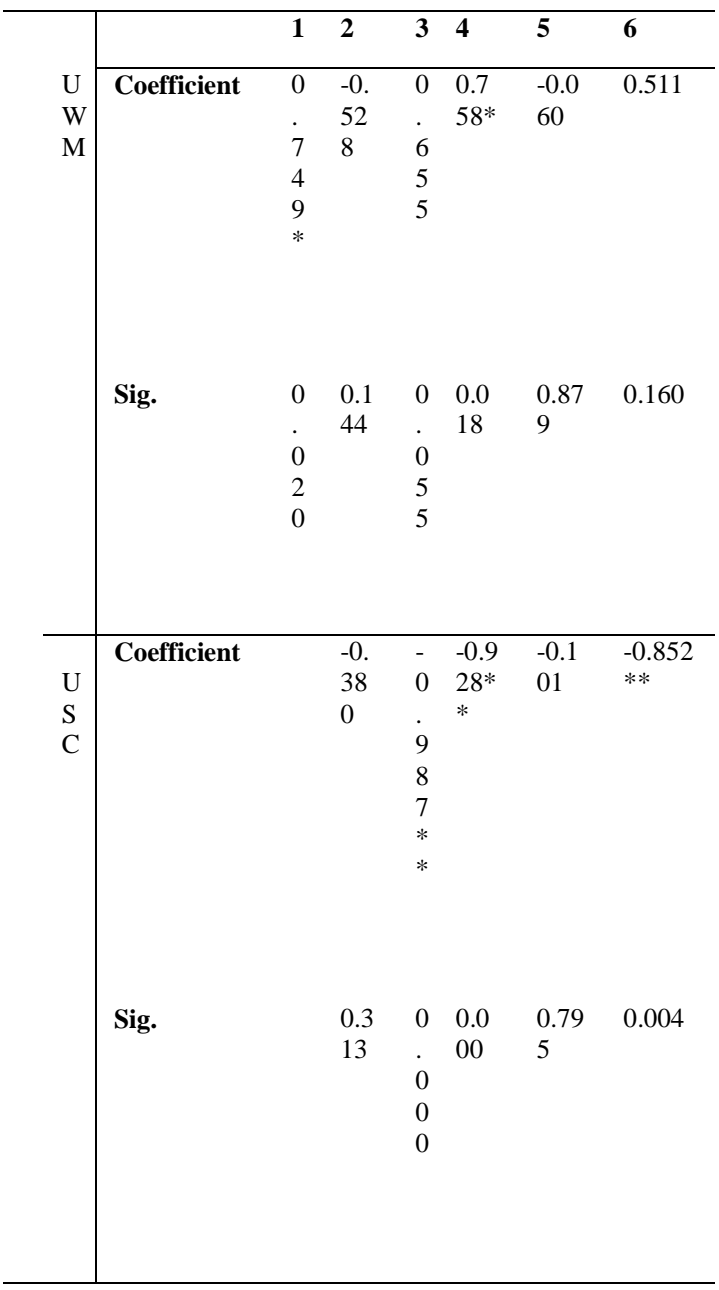

*.Correlation is significant at the 0.05 level (2-tailed); **.Correlation is significant at the 0.01 level (2-tailed).

Note: This article was selected analytic tools and Excel analysis software SPSS16.0, data from the U.S. National Center for Education Statistics released two schools 2002 2011 years of financial statements.

2) Regression analysis between university funds source structure and rankings

First, create a regression equation model:

$$
\begin{gathered}
\mathrm{Y}(\text { rankings })=\alpha+\beta * 1 \quad \begin{array}{l}
\left(\mathrm{X}_{1}\right)+\gamma^{* 4}\left(\mathrm{X}_{2}\right) \\
(1) \mathrm{Y}(\text { rankings })=\alpha+\beta^{*} 3
\end{array} \\
\left(\mathrm{X}_{1}\right)+\gamma^{*} \quad\left(\mathrm{X}_{2}\right)+\delta^{*} 6\left(\mathrm{X}_{3}\right)
\end{gathered}
$$

Dependent variable: rankings; Independent variable $\mathrm{Xi}=1,2,3$. 。 $: 1,3,4,5 ; \beta, \gamma, \delta$ is the regression coefficient

The results are as follows:

Table 3 is on the prediction model established goodness of fit test and significance tests, in order to compare their 
predictions with the actual degree of fit between the occurrence.

TABLE 3 ANALYSIS OF VARIANCE ${ }^{\mathrm{b}}$

\begin{tabular}{llcc}
\hline $\mathbf{M}$ & $\mathbf{R} / \mathbf{R}^{2}$ & $\mathbf{F}$ & sig. \\
\hline 1 & $0.740^{\mathrm{a}} / 0.548$ & 4.246 & $0.062^{\mathrm{a}}$ \\
\hline 2 & $0.894^{\mathrm{a}} / 0.799$ & 7.930 & $0.016^{\mathrm{a}}$ \\
\hline & & & \\
\hline & & & \\
& & & $\begin{array}{r}\text { a::Predictions: (Constant) } 1,3 \\
\text { b:Dependent variable }\end{array}$
\end{tabular}

The model 1 in table $3, \mathrm{R}=0.740, \mathrm{R} 2=0.548$, that is to say, these variables can explain the funds source of UWM, government grants and contracts(2) funding as well as private donations(4), and affect the extent of university rankings accounted for $54.8 \%$. The model 1 in the table 3 , $\mathrm{F}=4.246$, sig. $=0.062>0.05$, it shows that, the established regression equation is not significant. Therefore, we can infer, relationship between university rankings private donations(4) and government grants and contracts(4) is correlation, but there is no causal relationship between them.

So, what causes financial funds and university rankings show correlation, rather than a significant causal relationship? From the above, the situation presented in chart 1 and chart 2, we hypothesis that may be due to inefficient using of funds, or because of the small sample size of the data cause regression results not established.

The regression results are as follows Equation 2, in table $3, \mathrm{R}=0.894 \mathrm{a}, \mathrm{R} 2=0.799$, these variables can be explained by the USC in funding structure tuition(3), private donations and contracts(4) as well as other(6) sources of funding for university rankings impact of $79.9 \%$. The model 2 in table 3 , $\mathrm{F}=7.930$, sig. $=0.016>0.05$, this value indicates that the regression equation is significant.

From the table 4, we know that, significant levels of constant term(C), tuition and fees(3), private donations and contracts(4) as well as others(6) are 0.000,0.066,0.294,0.836, the constant term of 65.505 , the regression coefficients are $-7.420,3.125,1.225$. Therefore, tuition and fees(3), private donations and contracts(4) and others(6) for university rankings have a significant impact.

Regression equation:

$\mathrm{Y}$ (Rankings) $=65.505-7.420 *$ Tuition $(\mathrm{X} 1)+3.125 *$ private donations and contracts $(\mathrm{X} 2)+1.225 *$ Other $(\mathrm{X} 3)$

TABLE 4 REGRESSION COEFFICIENTS ${ }^{\mathrm{a}}$

\begin{tabular}{ccccc}
\hline M & Un-stand & Stand & t & sig. \\
\hline C & 65.505 & 9.547 & 6.861 & 0.000 \\
3 & $-7.420 \mathrm{E}-8$ & 0.000 & -2.248 & 0.066 \\
4 & $3.125 \mathrm{E}-8$ & 0.000 & 1.150 & 0.294 \\
6 & $1.225 \mathrm{E}-8$ & 0.000 & 0.216 & 0.836
\end{tabular}

a:dependent variable(rankings)

\section{RESEARCH FINDINGS AND DEFICIENCIES}

A. Findings

1) Between university total investment and rankings exists linear relationship

University of Wisconsin-Madison(UWM) funds source structure of government funding and private donations, with the contract for the impacting of university rankings have significant correlation, that is to say, the more put in government appropriations(1) and private donations and contracts(4) two kinds of funds, the more its rankings move rearward; University of Southern California(USC) in the non-government funds tuition and fees(3), private donations and contracts(4) as well as others(6) of funds source structure three factors on the university rankings are highly correlated, namely, University of Southern California's tuition and fees is derived from the more private donations and contracts as well as other (educational activities services and scale the size of the subsidiary bodies and services, hospital revenue and operating income independent) sources of funding, the more forward talks about its rankings.

Therefore, we have the first conclusion: between the total investment for the university and rankings exists linear relationship, the more public universities invest more, the poorer rankings they get, however, the more the private universities invest, the better rankings they get, which may be due to the efficient use of funds related to the problem, and need to be further explored.

2) Different university funds source structure impacts on the university rankings are different

Empirical results show that, government grants and private donations and contracts, affecting public universities rankings, while private tuition, private donations and contracts as well as other sources of funding universities the private universities rankings factors.

In conclusion, the differences of university funds source structure have been impacted on the university rankings. The empirical results show that, the there exists relationship between the University of Wisconsin-Madison funds source structure and the university rankings, but no causal relationship; and the University of Southern California in funds source structure which is tuition and fees, private donations and contracts as well as other sources of funding for university rankings, the degree of influence respective is 1.255 and 7.42,3.125. The reason for this could be: first, the new U.S. published by the evaluation index system "financial position" and "alumni donations and contracts" weights differences; second, it is due to the different natures of university funds sources which lead to differences in the structure, for the public university funds mainly come from donations and government grants and government subsidies, while private university are mainly funded by private donations, tuition and contract.

\section{B. Deficiencies}

Perspective of this article is mainly from the total investment and funds source structure, summarized as follows: 
Firstly, each university funds source structure subjected to external economic environment factors is more obvious, without the exogenous variables including in the study, making the lack of a comprehensive study. Since the 2008 financial crisis in U.S., most universities increased the amount of tuition and fees, so the ripple effect a direct impacting assessments.

Secondly, the rating agencies announced evaluation inflexible, such as the new U.S. The latest evaluation system was revised in 2005, then the financial crisis economic situation changed, the corresponding index system lacks linkage mechanism. Therefore, the results of the assessment must be have some errors.

Again, because the data collection is difficult, only 10 years of statistical data would be given a limited impacting. Finally, by comparing to two universities funds usage, we speculate that structural differences lead to different sources of funding, may be due to the efficient using of funds, it is worth continuing to explore the issue.

\section{REFERENCES}

[1] Shi Jinghuan, Zhao Ke and Xia Hua, "Carnegie classification of institutions of higher education research universities in the United States”,J. Peking University Education Review, 2007,4 (5,2): 107.

[2] Yang Jianmei, "Carnegie Classification of Higher Education Institutions dialysis",J. Higher Engineering Education Research, 2002 (2) :73-76.

[3] Zhao Puguang. The commentary ranking assessment of development on the characteristics of foreign universities,J. "The Journal of Shandong Normal University(Humanities and Social Sciences)",2002(47,5):118-122.

[4] Resource:http://colleges.usnews.rankingsandreviews.com/best-colleg es. 